\title{
Identifying barriers to effective management of widespread invasive alien trees: Prosopis species (mesquite) in South Africa as a case study
}

\author{
Ross T. Shackleton ${ }^{\mathrm{a}, *}$, David C. Le Maitre ${ }^{\mathrm{b}}$, Brian W. van Wilgen ${ }^{\mathrm{a}}$, David M. Richardson ${ }^{\mathrm{a}}$ \\ a Centre for Invasion Biology, Department of Botany and Zoology, Stellenbosch University, Matieland 7602, South Africa \\ ${ }^{\mathrm{b}}$ Centre for Invasion Biology, Natural Resources and the Environment, CSIR, P.O. Box 320, Stellenbosch 7599, South Africa
}

\section{A R T I C L E I N F O}

\section{Article history:}

Received 7 September 2015

Received in revised form 14 March 2016

Accepted 23 March 2016

Available online 7 April 2016

\section{Keywords:}

Adaptation responses

Biological invasions

Invasive species

Tree invasions

Stakeholders

Environmental conservation

\begin{abstract}
A B S T R A C T
Biological invasions are a major driver of ecological and social change globally. The negative effects of these invasions have led to the initiation of programs to manage these invasions across the world. Management aims to reduce impacts and in some cases improve the benefits that some invasive species can provide. This study assesses the barriers that hinder the effective management of widespread tree invasions, drawing insights from a case study of invasions of Prosopis species (mesquite) in South Africa. We used questionnaire surveys and focussed workshops to identify barriers and adaption responses in four key stakeholder groups involved in different stages of management. More than 100 barriers were identified, most of them relating to social issues. Key barriers related to limited knowledge, insufficient funds, conflicts of interest, the ecology of the genus and the nature of the invaded land, as well as poor planning, co-ordination and co-operation, and a lack of prioritisation. There were marked differences in how stakeholders perceived the importance of some barriers. Most Farmers (>80\%) placed high importance on a lack of planning, and poor management as important barriers, while few Managers $(<20 \%)$ regarded these as important; this reflects different views about the context in which management projects operate. Workshops identified more barriers and, overall, provided greater insights into the dimensions of barriers. The questionnaires were, however, useful for providing quantitative data which helped to rank the importance of barriers amongst stakeholders. Although adaptation responses were identified, not all barriers are conducive to simple solutions. Among the most intractable barriers were the lack of adequate funds and factors relating to the ecology of Prosopis species. Problems such as adopting new clearing methods and strategic planning need to be overcome to improve the effectiveness of control with the available funds.
\end{abstract}

(c) 2016 Elsevier Ltd. All rights reserved.

\section{Introduction}

\subsection{Global change and barriers to adaption}

Invasive alien species cause major disruptions to socialecological systems and are a major driver of global change (Vitousek et al., 1997). Hundreds of species introduced accidently or intentionally over past centuries have had severe detrimental effects on biodiversity, ecosystem services and local economies (Pyšek and Richardson, 2010). The escalation of negative impacts associated with invasions has led to an increase in the number of management projects across the world that aim to reduce the

\footnotetext{
* Corresponding author.

E-mail addresses: rtshackleton@gmail.com (R.T. Shackleton), dlmaitre@csir.co.za (D.C. Le Maitre), bvanwilgen@sun.ac.za (B.W. van Wilgen), rich@sun.ac.za (D.M. Richardson).
}

negative effects of these invasions. Some of these projects have limited success (Wilson et al., 2011; van Wilgen et al., 2012a; Shackleton et al., 2014), mainly because they encounter barriers that hamper the effective management of the problem. Investigating barriers to adaptation and management is common in the fields of medicine (Flores and Vega, 1998; Gelland et al., 2011; Huang et al., 2011), psychology (Waller and Gilbody, 2009; Jansen van Vuuren and Learmonth, 2013) and climate change (Huang et al., 2011; Spires et al., 2014), but this practice has not yet been systematically incorporated into conservation biology or invasion science (but see UNEP, 2004; Roura-Pascual et al., 2009).

Barriers are factors that create obstacles or conditions that delay, hinder or divert the effectiveness of management, adaptation and transformation strategies (Moser and Ekstrom, 2010). Barriers affect individuals or households, but also operate at higher levels and influence cities, institutions, municipalities and governments (Robinson and Gore, 2005; Lorenzoni et al., 2007; Jantrasami et al., 2010; Lehmann et al., 2014). Different types of 
barriers exist, including biophysical (ecological, infrastructural), institutional (political, managerial) informational, economic and social barriers (cognitive, cultural, institutional, psychological) (Agrawal, 2008; Adger et al., 2009; Jones 2010; Gifford, 2011; Antwi-Agyei et al., 2013). A number of these barriers are contextual and relate to historical processes and include multiple stressors (Jansen van Vuuren and Learmonth, 2013; Shackleton et al., 2013).

Identifying and recognising barriers to effective management is an important early step in overcoming them. We suggest that it is important to investigate these issues from multiple viewpoints as different stakeholders face different problems and all have unique perspectives, all of which must be recognized when formulating management plans and policies. Overcoming such barriers requires concerted efforts by all stakeholders to make changes; there is need for adaptive management, new ways of thinking, effective legislation, institutional arrangements prioritisation of goals and sound strategic planning (Moser and Ekstrom, 2010). The timeous identification of barriers can facilitate more efficient planning of adaptation and management strategies by considering and implementing appropriate solutions (Moser and Ekstrom, 2010). The lack of research on barriers facing managers of invasive species may be hindering effective management, especially for large-scale operations such as the ambitious Working for Water (WfW) programme in South Africa (van Wilgen and Wannenburgh, 2016). We suggest that improving our understanding of the barriers that potentially hamper the effective management of invasive species could improve management and help to guide adaptive responses for combatting this major driver of global change.

\subsection{Tree invasions}

Until recently invasive alien trees were not widely recognised as a major threat to biodiversity and ecosystem productivity, but trees are now considered among the most widespread and damaging of invasive species globally (Richardson and Rejmánek, 2011). Invasive trees are now a major contributor to global change and negatively affect biodiversity, ecosystem services and human livelihoods (Shackleton et al., 2014). However, some invasive trees provide benefits as well as costs, leading to conflicts of interests surrounding their use and management (Dickie et al., 2014; van Wilgen and Richardson, 2014). Attempts to control spread range from ad hoc local-scale efforts by private land owners to large-scale national programs driven by national and international policies and agencies (Richardson and Rejmánek, 2011; Brundu and Richardson, 2016). There are cases where management has reduced problems associated with tree invasions, but also case studies where projects have failed to achieve effective management (van Wilgen et al., 2012a). Further investigation to elucidate the most important barriers to the management of tree invasions is warranted, especially in developing countries. This is particularly important when developing strategic plans to observe international agreements such as the Convention on Biodiversity, and where attempts are made to comply with national policies that are in place in countries, including Australia, South Africa and the United States. Our study focusses on invasive Prosopis species in South Africa.

\subsection{Study species and system (Prosopis in South Africa)}

We used the genus Prosopis (mesquite), widely recognised as one of the worst and most widespread invasive tree taxa in the world (Shackleton et al., 2015b), as a case study. Prosopis species have been moved around the globe during the past century to provide local communities with resources, notably fodder and wood. Several species and their hybrids have naturalised and/or become invasive in over 100 countries, leading to negative impacts and conflicts of interest around use and management (Shackleton et al., 2014).

Prosopis species were first introduced to South Africa in the late 1800 s, and then in the mid-1900s they were distributed to farmers in large numbers across the arid central parts of South Africa to provide fodder and shade for livestock, and for fuelwood (Zimmermann, 1991; Poynton, 2009). Prosopis species have now invaded at least 1.8 million ha of South Africa, are still spreading at rates between 3.5 and $8 \%$ per annum, and have the potential to invade a further 58 million ha of the country (Versfeld et al., 1998; Rouget et al., 2004; Van den Berg et al., 2013). Prosopis was ranked as the second most widespread invasive plant taxon in South Africa after Australian Acacia species (Henderson, 2007) and Prosopis is also ranked highly for its impacts on biodiversity and ecosystem services (Le Maitre et al., 2000). Prosopis invasions in South Africa have negative impacts on biodiversity (reviewed in Shackleton et al., 2015a,b), ecosystem services such as grazing potential and water supply (Ndhlovu et al., 2011; Dzikiti et al., 2013), and livelihoods (Wise et al., 2012; Shackleton et al., 2015c). The benefits from Prosopis have been found to be less important than was previously thought, and most stakeholders support more aggressive management interventions (Shackleton et al., 2015d).

Due to the costs associated with Prosopis invasions, there has been active management to reduce impacts by the state-run WfW programme as well as by private land owners (Shackleton et al., 2015c). Current approaches include mechanical, chemical and biological control methods (Richardson 1998; van Wilgen et al., 2012a,b). Biological control has been largely been ineffective; one agent (Neltumius arizonensis) failed to establish and the others (Algarobius bottimeri and A. prosopis) have not substantially slowed rates of spread (Zachariades et al., 2011). There have been some localised successes using chemical and mechanical control, but overall management success is limited and the impacts and costs of Prosopis invasions are rising rapidly (Wise et al., 2012; van Wilgen et al., 2012a). Although WfW has spent R 435.5 million (US\$ 25.9 million) between 1996 and 2008 on managing Prosopis invasions, mesquite continues to increase its range and density rapidly across the county (van Wilgen et al., 2012a). This suggests that there may be barriers to the effective management of Prosopis (as is the case with other well-established invasive tree species in South Africa; e.g. Holmes et al., 2008; Roura-Pascual et al., 2009). The systematic investigation of these barriers, drawing on perspectives of key stakeholder groups involved in management, has the potential to improve the efficiency of management.

\subsection{The Working for Water programme}

The legacies of South Africa's apartheid past include unemployment, inequality and poverty-issues that need to be addressed by providing people with meaningful work and skills while ensuring sustainability. The WfW programme, a state publicworks program managed by the national Department of Environmental Affairs, therefore has multiple aims. The key aims are (1) to provide jobs and skills development to previously disadvantaged communities and (2) to manage and remove invasive alien species to reduce their negative impacts on the environment and restore the supply of ecosystem services (van Wilgen et al., 2012b). There are multiple tiers of management and implementation in the programme. WfW's activities are managed at national and provincial levels through implementing agents (government departments, municipalities, and conservation, forestry and agricultural authorities). These agents appoint local contractors, mainly from previously disadvantaged backgrounds, to conduct clearing work on a short-term (2-3 month) contract basis (van Wilgen and Wannenburgh, 2016). These contractors employ 
teams of 10 unskilled workers who are paid an agreed sum to clear demarcated areas based on norms and standards agreed on for different species, terrains and density classes (van Wilgen and Wannenburgh, 2016). These projects are supervised by regional managers, who are employed by the implementing agents on a more secure long-term basis. WfW clearing projects are conducted on both state and private land which involves working with additional stakeholders such as farmers. This programme is wellfunded compared to other environmental programmes in Africa and receives approximately $\mathrm{R} 1.8$ billion annually to control invasions across the country (van Wilgen et al., 2012b). The LandUser Incentives program also allows for groups of land owners (e.g. conservancies) to apply for funding from the state to manage invasions on their land. The different aims and the incorporation of multiple tiers of stakeholders have led to considerable complexity and the creation of unique barriers for each group.

This paper examines barriers to Prosopis management as perceived by multiple stakeholders and explores the adaptation responses that would be needed to overcome these barriers.

\section{Methods}

\subsection{Study area}

Prosopis invasions are found in the semi-arid and arid interior of South Africa, with the majority of invasive populations occurring in the Northern Cape Province (Richardson et al., 2000; Shackleton et al., 2015b). Extensive invasions occur in three major South African biomes: the Savanna, the Nama Karoo and Succulent Karoo with small populations also occurring in Fynbos, and Arid Grasslands (Shackleton et al., 2015b). Rainfall in invaded areas ranges from 150 to $450 \mathrm{~mm} \mathrm{yr}^{-1}$ and includes winter, summer and bimodal rainfall regimes. Altitudes range from 700 to $1300 \mathrm{~m}$ above sea level. The economy of the area is based on livestock agriculture, cropping along rivers, mining and tourism. More than twenty years after the dismantling of apartheid, the legacy of this social system is still evident in the distribution of different racial groups across the area within which Prosopis occurs. The most common land use is rangeland farming, which is dominated by

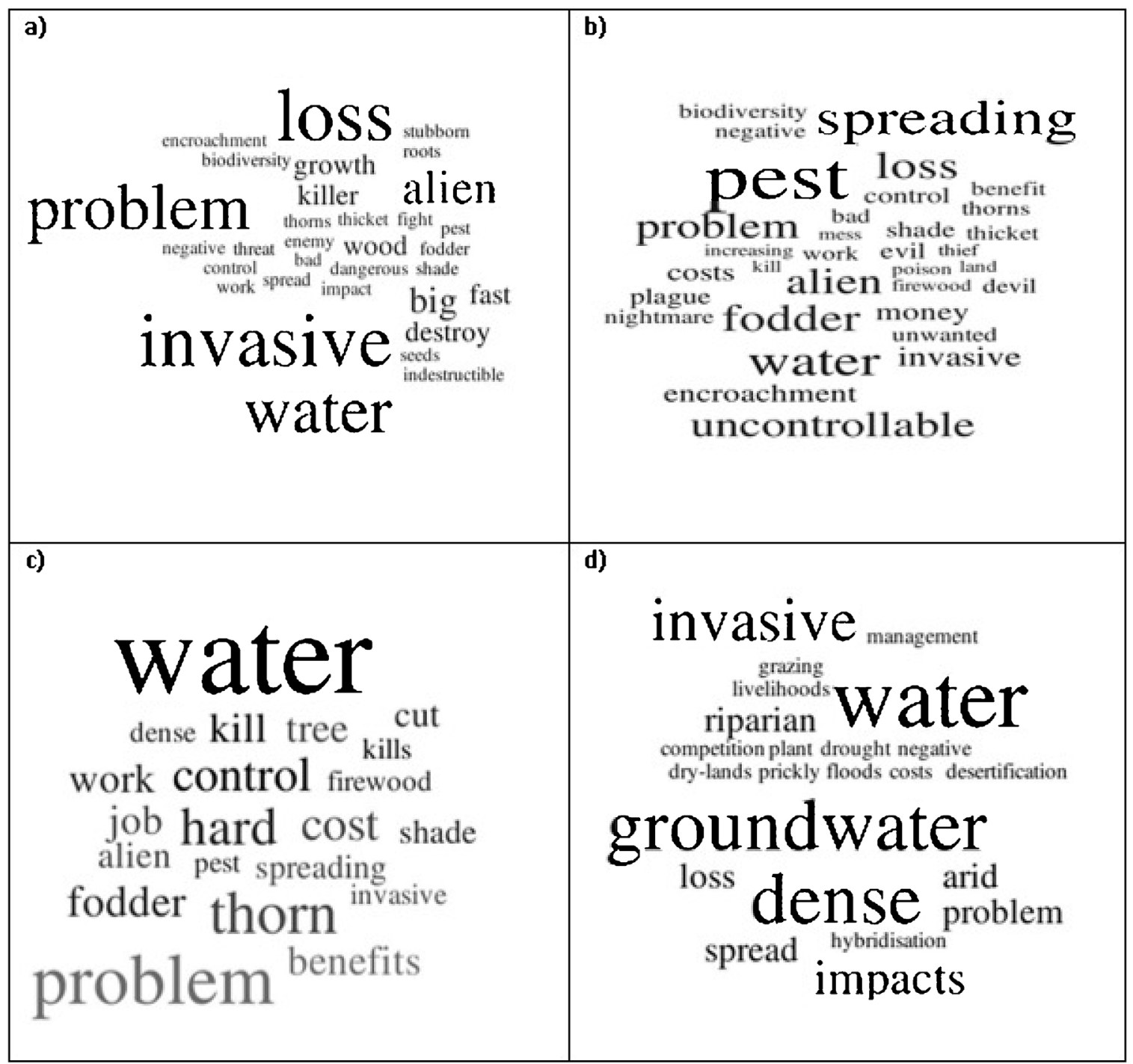

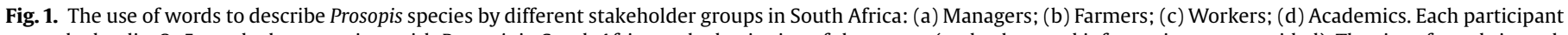

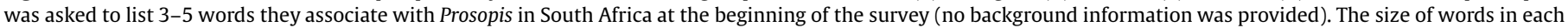
word cloud denotes the number of times that word was used. 
White landowners. There are also large areas of communal land that are populated by Black and mixed-race people. Stark socialeconomic divides exist between different communities (a legacy of apartheid), resulting in areas of high unemployment, poverty and inequality (Treiman, 2007; Shackleton et al., 2015c). This reality and the need for social transformation exacerbate the challenge of achieving sustainable management and conservation strategies.

\subsection{Questionnaires and workshops}

Interviews using semi-structured questionnaires were conducted and focussed workshops were held with four key stakeholder groups involved with different stages in the management of Prosopis. These four groups were:

1. Academics who undertake research on invasions, including their benefits, costs, ecology and management, and whose work is used to inform managers and policy makers. (Academics included people who had published peer-reviewed papers on Prosopis and/or management of invasive trees).

2. Farmers who live on private land and who manage invasions themselves, using their own labour and funds, but often supplemented by the state-run WfW programme or funded through its Land-User Incentives programme.

3. Managers employed by WfW who are involved in planning and overseeing invasive clearing projects; and

4. Workers employed by WfW from previously disadvantaged communities (often with low education and living in poverty), who receive a minimal payment and training from the WfW programme for manually clearing invasive species.

Ninety-five questionnaires were administered to the four groups: 11 to Academics, 34 to Farmers, 17 to Managers and 33 to Workers. Most of the managers on Prosopis-related projects run by WfW, and the academics in South Africa were sampled, and sub-sets of farmers and workers were located at multiple points in the Northern Cape. The questionnaire included questions relating to perceptions of Prosopis benefits and impacts, identification (free listing) and ranking barriers to management and possible adaptation responses (free listing). Interviews were conducted in English and Afrikaans depending on the preference of the interviewee. Qualitative methods (focus groups/workshops) were also used for reasons highlighted in Jones and Boyd (2011). Separate focussed workshops were held with each of the different stakeholder groups with between 10 and 20 participants to identify barriers relating to the effective management of Prosopis in South Africa. Each workshop lasted 1-1.5 h. Proceedings were recorded to allow us to refer back to clarify issues and to identify underlying themes. Each of the barriers listed in the questionnaire and the workshop were added separately and not pooled into predefined groups as done in other studies (e.g., Jantrasami et al., 2010).
The information from the questionnaires and workshops was summarised using the framework presented in Jones (2010) which categorises barriers into: (1) human and information factors (knowledge, economic and technological); (2) Natural factors (ecological and physical) and (3) social factors (cognitive, institutional and normative).

\subsection{Statistics}

Maximum likelihood Chi-square $\left(\chi^{2}\right)$ tests were used to assess where there were differences in perceptions of Prosopis and listing of barriers and adaption responses (categorical data) between the four stakeholder groups. Bonferroni post-hoc tests using adjusted standardised residuals (García-pérez and Núñez-antón, 2003) were also applied to these data. One-way ANOVAs, Kruskal-Wallis and Tukey post-hoc tests were used to determine whether differences existed between the number of barriers and adaption responses listed by different stockholder groups and the ranking of Prosopis benefits and costs between different stakeholders.

\section{Results}

\subsection{Perceptions of Prosopis}

When listing terms associated with Prosopis, the words: "water", "problem", "invasive" and "alien", and other words associated with impacts and management were commonly mentioned by all stakeholder groups (Fig. 1). However, there were also major differences between groups. Workers commonly mentioned words relating to work and job creation and well as verbs relating to the removal of Prosopis. Farmers also listed descriptive or modifying terms with negative connotations relating to the tree such as "plague", "thief", "evil" and "nightmare". Managers and Academics listed similar words, but typically using less emotive terms than Farmers or Workers.

All stakeholders involved in the management of Prosopis perceived invasive stands to have negative impacts (Table 1 ). The impacts rated most highly by all stakeholders related to water, grazing and biodiversity. Managers and Farmers rated impacts on the economy significantly higher than did Academics or Workers (Table 2). Similarly, Farmers and Workers rated impacts of infrastructure significantly higher than did Mangers and Academics. Most respondents in all stakeholder groups also perceived Prosopis to have benefits, with Managers and Farmers holding this view significantly more often than Workers and Academics (Table 1). All stakeholders considered the costs to be greater than the benefits, with Workers suggesting this significantly less than other stakeholder groups (Table 1). The provision of fodder, fuelwood and shade were rated as being among the most important benefits by all stakeholder groups. However, Workers rated fodder and fuelwood production from Prosopis to be significantly higher other stakeholder groups (Table 2). The

Table 1

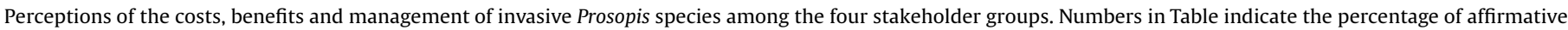

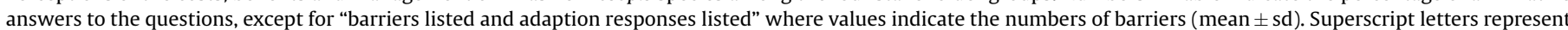
significance differences between stakeholders using Bonferroni and Tukey's post-hoc tests.

\begin{tabular}{|c|c|c|c|c|c|}
\hline Perceptions & Managers & Farmers & Workers & Academics & ANOVA and $\chi^{2} \mathrm{p}$-values \\
\hline Does Prosopis have costs? & $100^{\mathrm{a}}$ & $100^{\mathrm{a}}$ & $100^{\mathrm{a}}$ & $100^{\mathrm{a}}$ & $\mathrm{p}>0.05$ \\
\hline Does Prosopis have benefits? & $94^{\mathrm{a}}$ & $100^{\mathrm{a}}$ & $90^{\mathrm{a}}$ & $73^{\mathrm{b}}$ & $\mathrm{p}<0.005$ \\
\hline Costs $>$ Benefits? & $100^{\mathrm{a}}$ & $96^{\mathrm{a}}$ & $94^{\mathrm{b}}$ & $100^{\mathrm{a}}$ & $\mathrm{p}<0.05$ \\
\hline Need for management? & $100^{\mathrm{a}}$ & $100^{\mathrm{a}}$ & $100^{\mathrm{a}}$ & $100^{\mathrm{a}}$ & $\mathrm{p}>0.05$ \\
\hline Are there barriers to management? & $100^{\mathrm{a}}$ & $100^{\mathrm{a}}$ & $100^{\mathrm{a}}$ & $90^{\mathrm{a}}$ & $\mathrm{p}=0.03$ \\
\hline Barriers listed & $4.3 \pm 0.8^{\mathrm{a}}$ & $6.5 \pm 3.1^{\mathrm{b}}$ & $4.0 \pm 2.4^{\mathrm{a}}$ & $5 \pm 1.9^{\mathrm{b}}$ & $\mathrm{p}<0.001$ \\
\hline Adaptation responses listed & $3.8 \pm 1.9^{\mathrm{a}}$ & $3.3 \pm 1.0^{\mathrm{ac}}$ & $1.6 \pm 1.0^{\mathrm{b}}$ & $3.2 \pm 0 .^{\mathrm{ac}}$ & $\mathrm{P}<0.001$ \\
\hline
\end{tabular}


Table 2

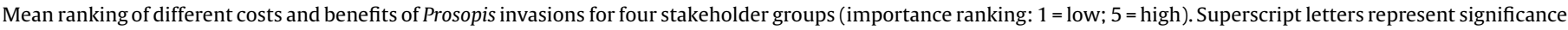
between stakeholders using Kruskal-Wallis post hoc-tests.

\begin{tabular}{|c|c|c|c|c|c|}
\hline Costs/Benefits & Managers & Farmers & Workers & Academics & Kruskal-Willis p-value \\
\hline \multicolumn{6}{|l|}{ Costs } \\
\hline Water & $4.9^{\mathrm{a}}$ & $4.5^{\mathrm{a}}$ & $4.8^{\mathrm{a}}$ & $4.5^{\mathrm{a}}$ & $p=0.06$ \\
\hline Grazing & $4.4^{\mathrm{a}}$ & $4.1^{\mathrm{a}}$ & $4.8^{\mathrm{a}}$ & $4.1^{\mathrm{a}}$ & $\mathrm{p}=0.08$ \\
\hline Biodiversity & $3.8^{\mathrm{a}}$ & $4.4^{\mathrm{a}}$ & $4.0^{\mathrm{a}}$ & $4.0^{\mathrm{a}}$ & $\mathrm{p}=0.44$ \\
\hline Encroachment & $3.9^{\mathrm{a}}$ & $4.5^{\mathrm{b}}$ & $3.9^{\mathrm{a}}$ & $4.0^{\mathrm{a}}$ & $\mathrm{p}=0.2$ \\
\hline Economy & $4.7^{\mathrm{a}}$ & $4.6^{\mathrm{a}}$ & $4.1^{\mathrm{a}}$ & $4.3^{\mathrm{a}}$ & $\mathrm{p}=0.08$ \\
\hline Infrastructure & $3.1^{\mathrm{a}}$ & $4.2^{\mathrm{b}}$ & $4.0^{\mathrm{b}}$ & $2.3^{\mathrm{a}}$ & $\mathrm{p}<0.01$ \\
\hline \multicolumn{6}{|l|}{ Benefits } \\
\hline Fodder & $2.7^{\mathrm{a}}$ & $3.0^{\mathrm{b}}$ & $3.7^{\mathrm{b}}$ & $3.0^{\mathrm{ab}}$ & $\mathrm{p}<0.04$ \\
\hline Fuelwood & $3.7^{\mathrm{ab}}$ & $2.7^{\mathrm{a}}$ & $4.5^{c}$ & $2.6^{\mathrm{cb}}$ & $\mathrm{p}<0.01$ \\
\hline Medicinal & $1.6^{\mathrm{a}}$ & $1.0^{\mathrm{b}}$ & $1.0^{\mathrm{b}}$ & $1.5^{\mathrm{a}}$ & $P=0.03$ \\
\hline Shade & $3.4^{\mathrm{a}}$ & $2.3^{\mathrm{b}}$ & $3.0^{\mathrm{a}}$ & $1.9^{\mathrm{b}}$ & $\mathrm{p}=0.02$ \\
\hline Edible products & $1.2^{\mathrm{a}}$ & $1.0^{\mathrm{b}}$ & $1.0^{\mathrm{b}}$ & $1.3^{\mathrm{ab}}$ & $\mathrm{p}=0.01$ \\
\hline
\end{tabular}

provision of shade was rated significantly higher by Managers and Workers than other stakeholder groups.

Respondents from all stakeholder groups felt that there was a need to reduce invasions and control the spread of Prosopis, and most respondents in all stakeholder groups recognized that there were barriers preventing effective management. However, this was mentioned significantly less often by Workers (Table 1). On average, stakeholders mentioned 4.0-6.5 different barriers relating to the management of Prosopis using questionnaires, with Farmers identifying significantly more barriers (Table 1). On average, stakeholders mentioned 1.6-3.8 adaption responses; Workers mentioned significantly fewer than other groups (Fig. 1).

\subsection{Barriers to management}

The results were categorised according to the framework used by Jones (2010) (Figs. 2-4 and Table 3). Most barriers fell into the social node, followed by the human and information node and lastly the natural node, although the barriers found within different nodes interlink with each other. The involvement of different stakeholder groups resulted in a more comprehensive understanding of impediments to management, as different groups clearly perceived different combinations of barriers (Figs. 2-4 and Table 3). Over 100 barriers were identified across the four stakeholder groups. Thirty-nine more or less discrete barriers affecting the management of Prosopis were listed by four stakeholder groups in the questionnaires (Table 3). Farmers mentioned the most barriers (26), followed closely by Academics (24), and Managers and Workers (19 and 15 respectively). In the workshops the four stakeholder groups identified 100 more or less discrete barriers with Academics, Managers, Farmers and Workers identifying 56, 50, 38 and 19 respectively (Fig. 2).

\subsection{Human and informational barriers}

Over 25 factors in the human and informational node were mentioned. These included lack of knowledge associated with Prosopis and invasion science and the fact that the awareness of what we do know is poor; a research-implementation gap also exists (Table 3; Fig. 2). The lack of knowledge mainly covers factors relating to the effectiveness of different control techniques as well as distributions, taxonomy and negative impacts of Prosopis invasions (Fig. 2). Interestingly, Managers highlighted that there was a lack of knowledge (53\%) and a lack of awareness of existing knowledge (41\%) significantly more than other stakeholder groups (Table 3).

The technological node included barriers relating to the underutilisation of potential management approaches (control
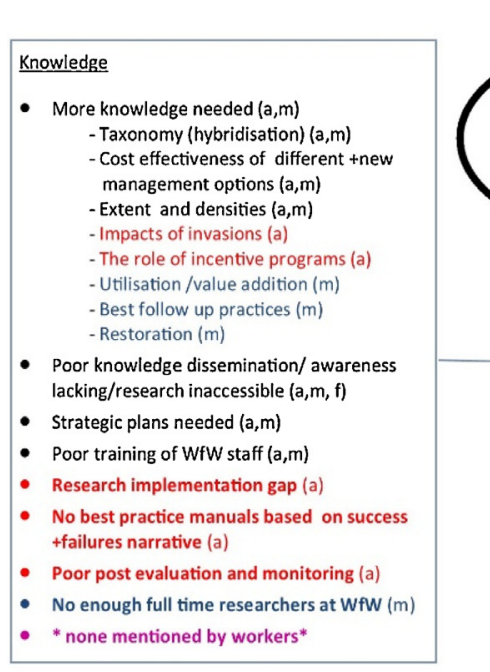

Key

"Workers only "Managers only

$* 1$ stakeholder group

Technological

- Lack of biological control $(a, f)$

- Ineffective herbicides $(m, f, w)$

- Use of mechanised methods $(m, f)$

- Should be utilising it (f)

- Not enough mechanical equipment provided (w)

- Equipment breaks often (w)

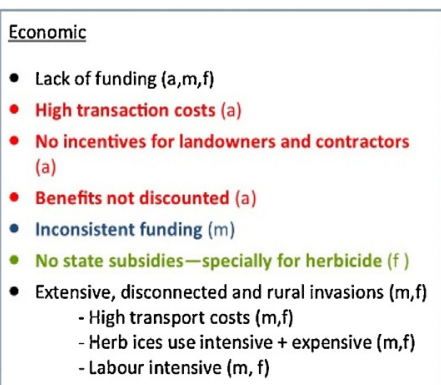

- South Africa is a developing nation with many social and economic inequalities that get priority over environmental issues (a.m, $f$ )
- The Northern Cape is a large province with widely dispersed populations -lease priority as compared to other provinces (a)
- Noed land value in the areas that Prosopis invades $(a)$
- State grant systems make labour hard to get $(f)$

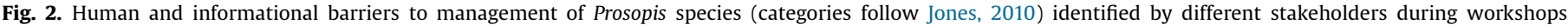

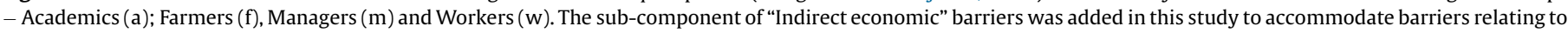
limited financial resources typical of a developing country. 


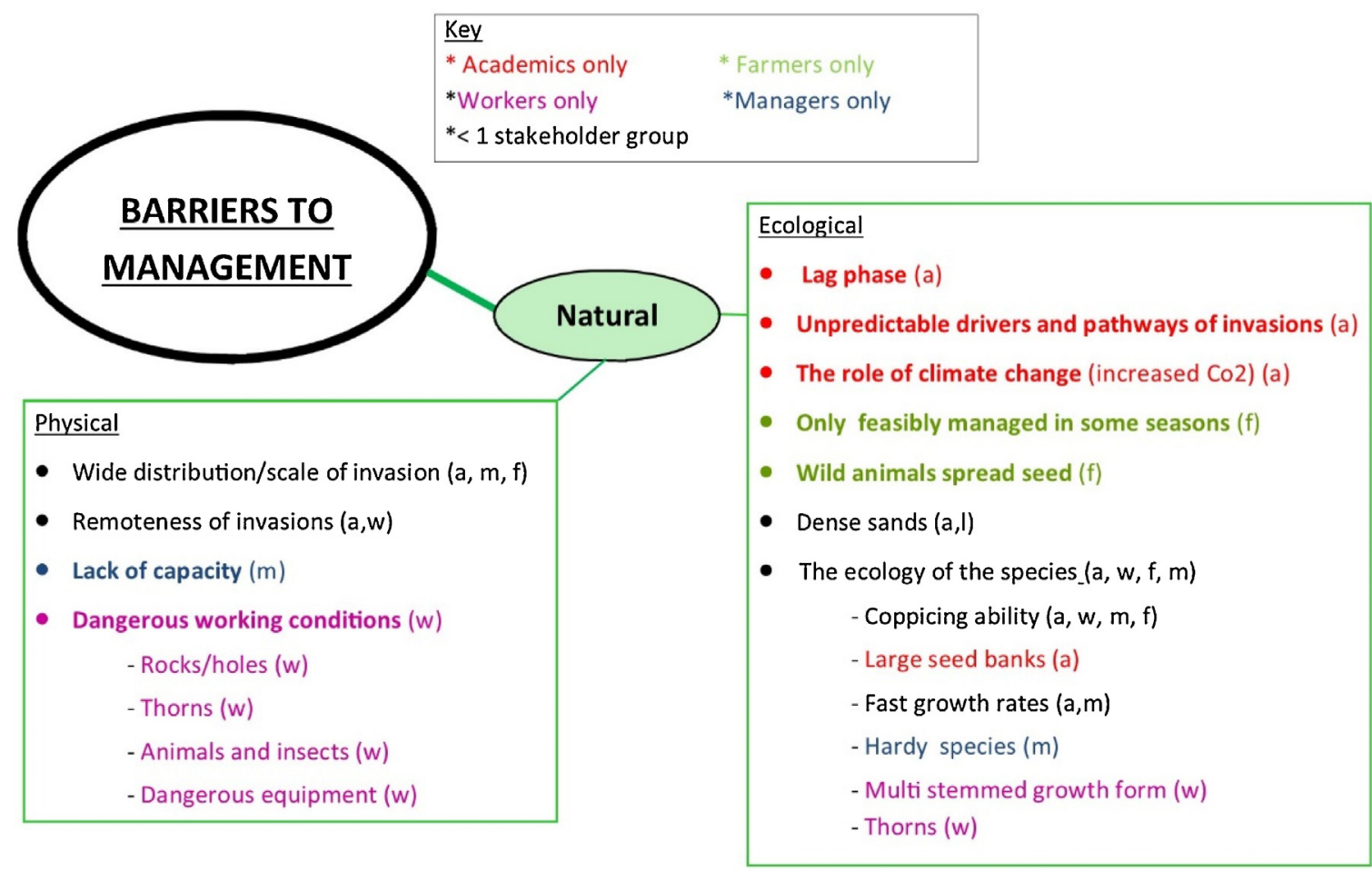

Fig. 3. Natural barriers to management (Jones, 2010) identified by different stakeholders in workshops: Academics (a); Farmers (f), Managers (m) and Workers (w).

through utilisation, biological control and use of heavy machinery) as well as issues with the type and quantity of equipment being used to clear trees. It was raised that the overriding WfW mandate to provide jobs was hindering the use of faster and more costeffective methods. Other barriers also included the incorrect use of herbicide, particularly applying it too long after felling. In the workshops Farmers mentioned that local WfW project managers were selling allocated herbicide to other farmers, and replacing it with diluted herbicide resulting in ineffective control due to coppicing. Another example of corruption was local WfW operating managers claiming they had cleared land and receiving payment for this, when the area was actually cleared by the farmer a few months earlier.

The economic barriers included lack of funding, inconsistent funding and factors relating to the lack of government subsidies and financial incentives for management by private land owners (Table 3; Fig. 2). Funding constraints were ranked significantly higher by Managers than other stakeholder groups (Table 3 ). Widespread invasions also have particularly high input costs, especially for species like Prosopis that can coppice and require herbicide. Interestingly, no Workers listed any economic barriers. We also added an extra sub-component (Indirect economic barriers) to the human and informational node which was not identified in the Jones (2010) framework (Fig. 2). Although some of these indirect economic factors are context-specific and relate to unique landscapes and historical processes, some of them will apply to other developing countries, especially in arid areas with low population densities. These include: (a) South Africa's colonial and apartheid history, where people were deprived of opportunities for education and employment - there is therefore great pressure to improve equality through the provision of infrastructure such as housing, schools and hospitals, which leads to less funding being available for environmental issues (Fig. 2); (b) The effects of social grants from government lead to a reduced incentive to work in jobs that pay low wages; and (c) The other indirect economic factors arose because the areas invaded by Prosopis are extensive, arid and are sparsely populated by people. This results in higher costs for management (and less incentive to manage) because the productive value of the land (return on investment) in this region is low compared to other parts of South Africa.

\subsection{Natural barriers}

Natural barriers to management were mentioned least often but still are viewed as having a major impact on the success of control operations (Fig. 3 and Table 3). They included physical factors, such as extensive and dense invasions, the remoteness of areas, lack of capacity, and dangerous working conditions (the last point was only mentioned by Workers) (Fig. 2). Ecological barriers, relating to invasion processes, the ecology and traits of the tree, and climate change, were mentioned. The increased presence of wildlife was sometimes attributed to Prosopis invasions. Wild animals that feed on Prosopis can spread the seeds across fence lines, including kudu (Tragelaphus strepsiceros) and baboons (Papio ursinus) that go over fences, and porcupines (Hystrix africaeaustralis) that burrow under fences. The dissemination of mesquite by livestock was also a key issue and is controversial in that some farmers still want to use Prosopis to feed livestock.

\subsection{Social barriers}

Social barriers were frequently mentioned by all the stakeholder groups, but to a lesser extent by Workers (Fig. 4 and Table 4). Cognitive barriers included feelings of hopelessness and apathy, loss of interest, failure to accept and learn from other examples (Fig. 4), and were mentioned significantly more by Farmers than other groups. Additionally, Farmers (55\%) suggested that other farmers wanted government support to clear their land and were not doing anything themselves. Respondents from all stakeholder 


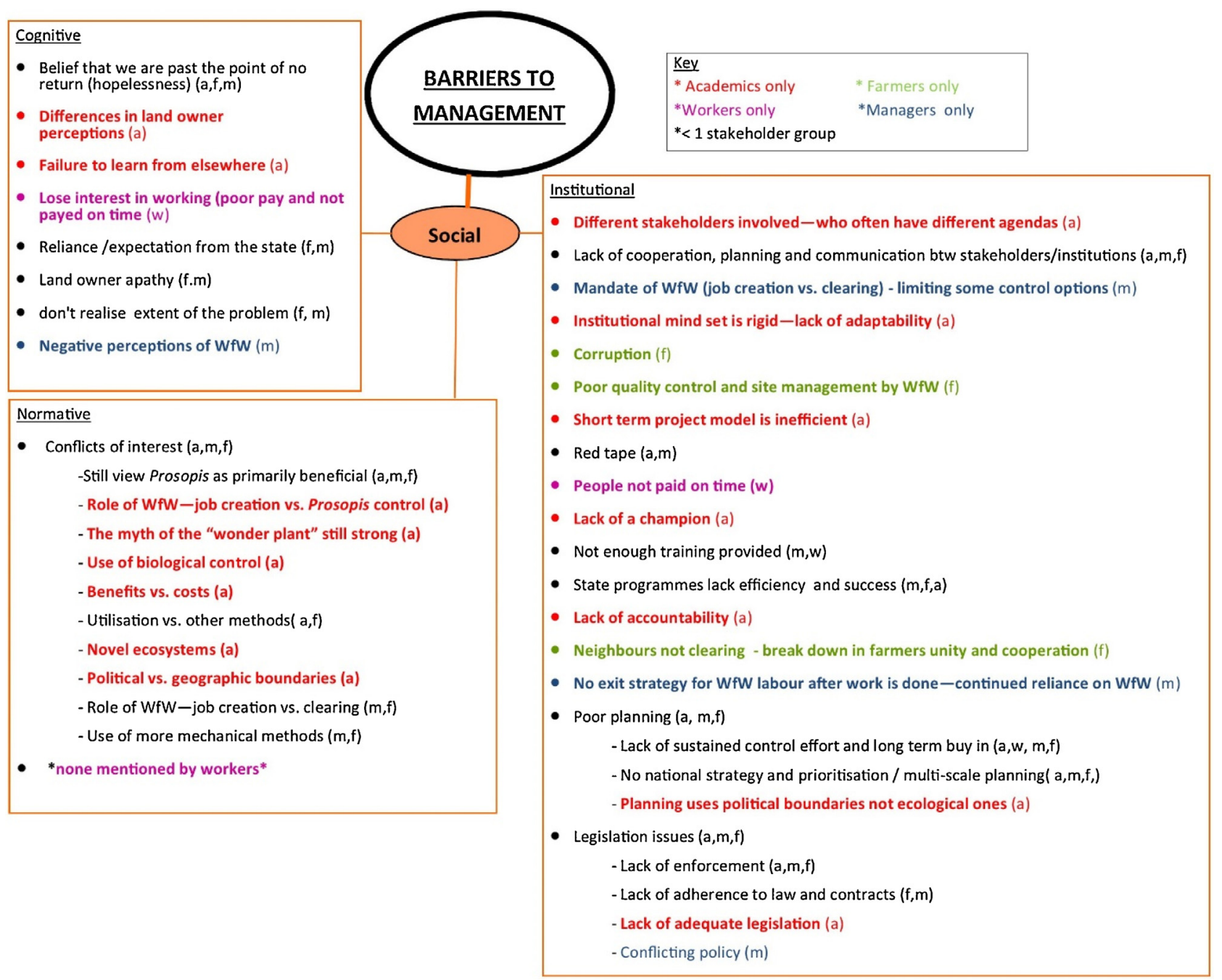

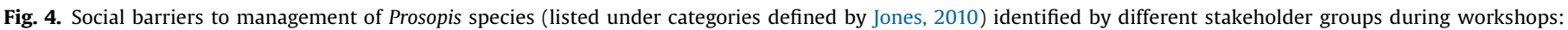
Academics (a); Farmers (f), Managers (m) and Workers (w).

groups suggested that some people still viewed mesquite as useful and not a big problem, which may be linked to the lack of awareness highlighted in the barriers to knowledge node (Fig. 4).

The normative barriers all related to the conflicts of interest or differences of opinion, and were mentioned most by Academics and not at all Workers (Fig. 4 and Table 3). This is related to contrasting views on the appropriateness of different management approaches. For example, the use of biological control or more mechanised clearing methods were seen by some as a way to become more effective, but by others as having the potential to reduce opportunities for employment). There were also contrasting views on whether or not utilization of cleared biomass would assist control or provide arguments for the retention of Prosopis in the landscape.

Institutional barriers were regularly mentioned, but differed significantly between stakeholder groups, particularly between Managers and Farmers (Fig. 4; Table 3). Major issues highlighted as institutional barriers included a lack of stakeholder cooperation and communication and partnerships which were highlighted by Managers (35\%) significantly more than other groups. Managers highlighted that communication between WfW based in the department of Environmental Affairs and other stakeholders involved in the management of Prosopis such as farmers, other government departments (e.g. Agriculture, Forestry and Fisheries; Water and Sanitation) and South African National Parks was poor.
A lack of strategic planning and prioritisation was emphasised particularly by Farmers (76\%) and Academics (64\%) but to a minor extent by Managers (18\%). It was suggested that a random ("shot-gun") approach to management ("little bits here and there") has been followed which is ineffective for addressing pathways of spread and that cleared sites are often reinvaded. Farmers also mentioned poor management, supervision and quality control as problems (95\%), poor follow-up clearing (88\%), corruption within the state-run WfW program (32\%), and the lack of cooperation between landowners (where one clears and the other does not) more than other stakeholder groups and were viewed as major issues affecting successful management (Table 3). Farmers felt that invasions are now worse than a decade ago and that poor management has led to widespread coppicing and the densification of invasive stands. Multiple narratives of corruption were discussed in the workshop; these include stories of Managers and contractors giving Farmers herbicides in return for sheep (bribes), WfW project sites being selected using bribes, and contractors being paid for clearing land that had in fact been cleared by the farmers themselves. Some of the institutional issues raised by Farmers were not of as much concern to Managers (Table 3). These discrepancies point to different world views among the most important stakeholders involved in management. Issues raised as major barriers by Academics more often (45\%) than by other groups included poor monitoring, institutional arrangements and 
Table 3

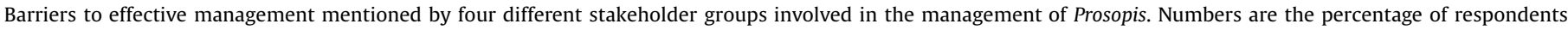

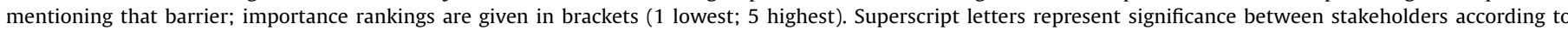
Bonferroni post-hoc tests.

\begin{tabular}{|c|c|c|c|c|c|}
\hline Barriers & Managers [\%(rank)] & Farmers [\%(rank)] & Workers [\%(rank)] & Academics $[\%($ rank $)]$ & $\chi^{2}$ p-value \\
\hline \multicolumn{6}{|l|}{ Human and Informational } \\
\hline \multicolumn{6}{|l|}{ Knowledge } \\
\hline Lack of knowledge & $53^{a}(4)$ & $0^{\mathrm{b}}$ & $0^{\mathrm{b}}$ & $9^{c}(4)$ & $\mathrm{p}<0.0001$ \\
\hline Lack of awareness & $41^{a}(3)$ & $0^{\mathrm{b}}$ & $0^{\mathrm{b}}$ & $9^{c}(4)$ & $\mathrm{p}<0.0001$ \\
\hline \multicolumn{6}{|l|}{ Technological } \\
\hline Ineffective herbicide & $35^{a}(4)$ & $35^{a}(5)$ & $42^{\mathrm{a}}(5)$ & $9^{\mathrm{b}}(5)$ & $\mathrm{p}=0.01$ \\
\hline Broken equipment & $0^{\mathrm{a}}$ & $0^{\mathrm{a}}$ & $12^{\mathrm{b}}(4)$ & $0^{\mathrm{a}}$ & $\mathrm{p}<0.005$ \\
\hline Lack of equipment & $0^{\mathrm{a}}$ & $0^{\mathrm{a}}$ & $52^{\mathrm{b}}(5)$ & $0^{\mathrm{a}}$ & $\mathrm{p}<0.0001$ \\
\hline Herbicide applied poorly & $29^{a}(4)$ & $38^{\mathrm{a}}(5)$ & $0^{\mathrm{b}}$ & $9^{\mathrm{b}}(3)$ & $\mathrm{P}<0.0001$ \\
\hline \multicolumn{6}{|l|}{ Economic } \\
\hline Funding constraints & $82^{a}(5)$ & $71^{a}(5)$ & $0^{\mathrm{b}}$ & $64^{\mathrm{a}}(5)$ & $\mathrm{p}<0.0001$ \\
\hline \multicolumn{6}{|l|}{ Natural } \\
\hline \multicolumn{6}{|l|}{ Physical } \\
\hline Capacity constraints & $29^{a}(4)$ & $0^{\mathrm{b}}$ & $0^{\mathrm{b}}$ & $9^{\mathrm{b}}(3)$ & $\mathrm{p}<0.005$ \\
\hline Time constraints & $0^{\mathrm{s}}$ & $32^{\mathrm{b}}(5)$ & $0^{\mathrm{a}}$ & $0^{\mathrm{a}}$ & $\mathrm{p}<0.0001$ \\
\hline Difficulty finding reliable labour & $0^{\mathrm{a}}$ & $61^{\mathrm{b}}(4)$ & $0^{\mathrm{a}}$ & $0^{\mathrm{a}}$ & $\mathrm{p}<0.0001$ \\
\hline Widespread invasions & $0^{\mathrm{a}}$ & $0^{\mathrm{a}}$ & $0^{\mathrm{a}}$ & $18^{\mathrm{b}}(5)$ & $\mathrm{p}=0.03$ \\
\hline Thorns & $0^{\mathrm{a}}$ & $12^{\mathrm{b}}(3)$ & $36^{c}(4)$ & $0^{\mathrm{a}}$ & $\mathrm{p}<0.005$ \\
\hline Dangerous working conditions & $0^{\mathrm{a}}$ & $0^{\mathrm{a}}$ & $10^{\mathrm{b}}(3)$ & $0^{\mathrm{a}}$ & $\mathrm{p}=0.01$ \\
\hline Large travel distances/isolated areas & $0^{\mathrm{a}}$ & $0^{\mathrm{a}}$ & $12^{\mathrm{a}}(3)$ & $9^{a}(5)$ & $\mathrm{p}=0.06$ \\
\hline \multicolumn{6}{|l|}{ Ecological } \\
\hline Fast growth and spread rates & $41^{\mathrm{a}}(5)$ & $15^{\mathrm{b}}(4)$ & $16^{\mathrm{b}}(4)$ & $45^{\mathrm{a}}(5)$ & $\mathrm{p}=0.002$ \\
\hline Ineffective biological control & $6^{a}(5)$ & $0^{\mathrm{a}}$ & $0^{\mathrm{a}}$ & $45^{\mathrm{b}}(5)$ & $\mathrm{p}<0.0001$ \\
\hline Hybridisation & $0^{\mathrm{a}}$ & $0^{\mathrm{a}}$ & $0^{\mathrm{a}}$ & $18^{\mathrm{b}}(4)$ & $\mathrm{p}<0.03$ \\
\hline Animals spread it (wild and domestic) & $17^{\mathrm{a}}(3)$ & $36^{\mathrm{a}}(4)$ & $0^{\mathrm{b}}$ & $9^{a}(4)$ & $\mathrm{p}<0.0001$ \\
\hline \multicolumn{6}{|l|}{ Social } \\
\hline \multicolumn{6}{|l|}{ Cognitive } \\
\hline Farmers rely on government/want subsidies & $0^{\mathrm{a}}$ & $55^{\mathrm{b}}(5)$ & $0^{\mathrm{a}}$ & $0^{\mathrm{a}}$ & $\mathrm{p}<0.0001$ \\
\hline Not perceived as a problem and still used & $17^{\mathrm{a}}(5)$ & $58^{\mathrm{b}}(5)$ & $0^{\mathrm{c}}$ & $45^{\mathrm{b}}(5)$ & $\mathrm{p}<0.0001$ \\
\hline \multicolumn{6}{|l|}{ Normative } \\
\hline Conflicts of interest & $0^{\mathrm{a}}$ & $14^{\mathrm{b}}(4)$ & $0^{\mathrm{a}}$ & $45^{c}(4)$ & $\mathrm{p}<0.0001$ \\
\hline \multicolumn{6}{|l|}{ Institutional } \\
\hline No strategic planning and prioritisation & $18^{\mathrm{a}}(5)$ & $76^{\mathrm{b}}(5)$ & $3^{c}(4)$ & $64^{\mathrm{b}}(5)$ & $\mathrm{p}<0.0001$ \\
\hline Red tape & $6^{a}(4)$ & $3^{\mathrm{a}}(3)$ & $6^{a}(4)$ & $0^{\mathrm{a}}$ & $\mathrm{p}=0.5$ \\
\hline Poor management, supervision and efficiency & $18^{\mathrm{a}}(5)$ & $98^{\mathrm{b}}(5)$ & $12^{\mathrm{a}}(3)$ & $36^{\mathrm{a}}(5)$ & $\mathrm{p}<0.0001$ \\
\hline No partnerships and communication btw stakeholders & $35^{a}(5)$ & $18^{\mathrm{a}}(5)$ & $0^{\mathrm{b}}$ & $18^{\mathrm{a}}(4)$ & $\mathrm{p}<0.005$ \\
\hline Projects to short term and irregular & $6^{\mathrm{a}}(4)$ & $14^{\mathrm{b}}(4)$ & $51^{\mathrm{c}}(5)$ & $18^{\mathrm{b}}(5)$ & $\mathrm{p}<0.0005$ \\
\hline WfW focus on job creation(mandates) & $0^{\mathrm{a}}$ & $23^{\mathrm{b}}(4)$ & $0^{\mathrm{a}}$ & $9^{a}(5)$ & $\mathrm{p}=0.01$ \\
\hline Poor follow up form WfW and farmers & $27^{\mathrm{a}}(4)$ & $88^{\mathrm{b}}(5)$ & $9^{\mathrm{a}}(5)$ & $9^{a}(4)$ & $\mathrm{p}<0.0001$ \\
\hline Compliance, enforcement of law/incorrect law & $13^{\mathrm{a}}(4)$ & $9^{\mathrm{a}}(3)$ & $0^{\mathrm{b}}$ & $18^{\mathrm{a}}(4)$ & $\mathrm{p}=0.04$ \\
\hline Poor monitoring & $0^{\mathrm{a}}$ & $18^{\mathrm{b}}(4)$ & $0^{\mathrm{a}}$ & $45^{\mathrm{b}}(5)$ & $\mathrm{p}<0.0001$ \\
\hline Corruption & $0^{\mathrm{a}}$ & $32^{\mathrm{b}}(3)$ & $0^{\mathrm{a}}$ & $0^{\mathrm{a}}$ & $\mathrm{p}<0.0001$ \\
\hline Neighbours do not manage it & $0^{\mathrm{a}}$ & $50^{\mathrm{b}}(5)$ & $0^{\mathrm{a}}$ & $0^{\mathrm{a}}$ & $\mathrm{p}<0.0001$ \\
\hline Unwilling to invest in rented land & $0^{\mathrm{a}}$ & $15^{\mathrm{b}}(3)$ & $0^{\mathrm{a}}$ & $0^{\mathrm{a}}$ & $\mathrm{p}=0.04$ \\
\hline Control in the wrong season & $0^{\mathrm{a}}$ & $6^{a}(3)$ & $0^{\mathrm{a}}$ & $0^{\mathrm{a}}$ & $\mathrm{p}=0.2$ \\
\hline Interference from farmers & $0^{\mathrm{a}}$ & $0^{\mathrm{a}}$ & $16^{\mathrm{b}}(3)$ & $0^{\mathrm{a}}$ & $\mathrm{p}=0.03$ \\
\hline Paid late & $0^{\mathrm{a}}$ & $0^{\mathrm{a}}$ & $60^{\mathrm{b}}(5)$ & $0^{\mathrm{a}}$ & $\mathrm{p}<0.0001$ \\
\hline Lack of training & $0^{\mathrm{a}}$ & $0^{\mathrm{a}}$ & $6^{\mathrm{a}}(3)$ & $9^{\mathrm{a}}(5)$ & $\mathrm{p}=0.6$ \\
\hline Lack of restoration & $6^{\mathrm{a}}(3)$ & $3^{\mathrm{a}}(4)$ & $0^{\mathrm{a}}$ & $9^{a}(4)$ & $\mathrm{p}=0.6$ \\
\hline
\end{tabular}

mandates, and a lack of a champion and accountability in the WfW programme (Table 3). The short-term and irregular nature of projects were also raised as an issue by all stakeholders, but particularly by Workers who found that this made it difficult for them to plan financially and led to them to leaving the WfW programme for more secure jobs when these arose. Short-term projects also often meant that re-growth was not cleared. Workers suggested that they were frequently not paid on time, which linked closely to the cognitive barriers of a loss of interest in employment in the WfW programme.

\subsection{Adaptation responses}

Around 25 adaptation responses were mentioned by the four stakeholder groups; each group mentioned 11-16 different responses (Table 4). There was considerable overlap between the responses listed by groups with the most common adaptation responses mentioned being: researching and using different approaches to management, including biological control, utilisation approaches, the development of new herbicides (a sub-point mentioned by all stakeholders), as well as using more mechanical approaches to improve control. Workers identified the need for more chainsaws to be made available (currently, only one chainsaw is provided to a team of 10 workers, which effectively means that only one person at a time can be actively engaged in felling trees). Farmers mentioned the importance of adopting more effective clearing methods, rather than focusing on job creation significantly more than other stakeholder groups. Future monitoring and indicators of success need to be broadened beyond simply listing the person-days worked as a means of evaluating the success of projects, and should include measures of improvements in ecosystem functionality. Improved awareness and research, the 
Table 4

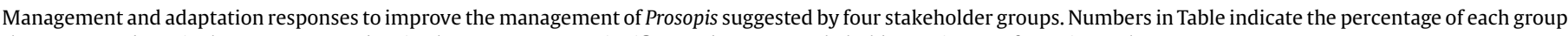
that suggested particular responses. Subscript letters represent significance between stakeholders using Bonferroni post hoc tests.

\begin{tabular}{|c|c|c|c|c|c|}
\hline Management/adaptation responses & Managers & Farmers & Workers & Academics & $\chi^{2}$ p-value \\
\hline Awareness and research programs & $35^{\mathrm{a}}$ & $38^{\mathrm{a}}$ & $0^{\mathrm{b}}$ & $18^{\mathrm{b}}$ & $\mathrm{p}<0.001$ \\
\hline Use and research diff. man. approaches & $58^{\text {ad }}$ & $100^{\mathrm{b}}$ & $9^{c}$ & $81^{\mathrm{d}}$ & $\mathrm{p}<0.0001$ \\
\hline More localised managers & $17^{\mathrm{a}}$ & $3^{\mathrm{b}}$ & $3^{\mathrm{b}}$ & $0^{\mathrm{b}}$ & $\mathrm{p}<0.001$ \\
\hline Better stakeholder engagement & $58^{\mathrm{a}}$ & $24^{\mathrm{a}}$ & $0^{\mathrm{a}}$ & $18^{\mathrm{a}}$ & $\mathrm{p}=0.09$ \\
\hline Use stronger herbicide & $12^{\mathrm{a}}$ & $23^{\mathrm{a}}$ & $40^{\mathrm{a}}$ & $9^{a}$ & $\mathrm{p}<0.13$ \\
\hline Increase budgets & $0^{\mathrm{a}}$ & $0^{\mathrm{a}}$ & $0^{\mathrm{a}}$ & $18^{\mathrm{b}}$ & $\mathrm{P}=0.15$ \\
\hline Less focus on job creation & $0^{\mathrm{a}}$ & $24^{\mathrm{b}}$ & $0^{\mathrm{a}}$ & $9^{\mathrm{b}}$ & $P=0.23$ \\
\hline Change and enforce legislation and contracts & $47^{\mathrm{a}}$ & $21^{\mathrm{a}}$ & $0^{\mathrm{b}}$ & $18^{\mathrm{a}}$ & $\mathrm{p}<0.01$ \\
\hline More access to managers & $0^{\mathrm{a}}$ & $21^{\mathrm{b}}$ & $0^{\mathrm{a}}$ & $0^{\mathrm{a}}$ & $\mathrm{p}<0.001$ \\
\hline Employ more teams & $6^{\mathrm{a}}$ & $0^{\mathrm{a}}$ & $15^{\mathrm{a}}$ & $0^{\mathrm{a}}$ & $P=0.06$ \\
\hline Projects more long term/more follow-ups & $35^{\mathrm{a}}$ & $48^{\mathrm{a}}$ & $3^{a}$ & $9^{a}$ & $P=0.13$ \\
\hline Understand and solve conflicts of interest & $0^{\mathrm{a}}$ & $0^{\mathrm{a}}$ & $0^{\mathrm{a}}$ & $27^{\mathrm{b}}$ & $\mathrm{p}<0.001$ \\
\hline Provide subsidies to farmers & $6^{\mathrm{a}}$ & $32^{\mathrm{b}}$ & $0^{c}$ & $0^{c}$ & $\mathrm{p}<0.001$ \\
\hline Restore cleared areas & $12^{\mathrm{a}}$ & $0^{\mathrm{a}}$ & $0^{\mathrm{a}}$ & $0^{\mathrm{a}}$ & $\mathrm{p}<0.09$ \\
\hline Disincentivise its use & $12^{\mathrm{a}}$ & $58^{\mathrm{b}}$ & $0^{\mathrm{c}}$ & $0^{\mathrm{c}}$ & $\mathrm{p}<0.0001$ \\
\hline Give teams more mechanical equipment & $0^{\mathrm{a}}$ & $0^{\mathrm{a}}$ & $55^{\mathrm{b}}$ & $0^{a}$ & $\mathrm{p}<0.001$ \\
\hline Strategic planning and prioritisation & $6^{a}$ & $48^{\mathrm{b}}$ & $3^{\mathrm{a}}$ & $63^{\mathrm{b}}$ & $\mathrm{p}<0.001$ \\
\hline Improve monitoring & $0^{\mathrm{a}}$ & $0^{\mathrm{a}}$ & $0^{\mathrm{a}}$ & $18^{\mathrm{b}}$ & $\mathrm{p}<0.01$ \\
\hline Get paid on time & $0^{\mathrm{a}}$ & $0^{\mathrm{a}}$ & $21^{\mathrm{b}}$ & $0^{\mathrm{a}}$ & $\mathrm{p}<0.01$ \\
\hline Improve training & $0^{\mathrm{a}}$ & $0^{\mathrm{a}}$ & $6^{\mathrm{a}}$ & $9^{\mathrm{a}}$ & $P=0.28$ \\
\hline Understand taxonomy & $0^{\mathrm{a}}$ & $0^{\mathrm{a}}$ & $0^{\mathrm{a}}$ & $27^{\mathrm{b}}$ & $\mathrm{p}<0.01$ \\
\hline Clamp down on corruption & $0^{\mathrm{a}}$ & $15^{\mathrm{b}}$ & $0^{\mathrm{a}}$ & $0^{\mathrm{a}}$ & $\mathrm{p}<0.01$ \\
\hline Breed sterile cultivars/id safe taxa to use & $0^{\mathrm{a}}$ & $6^{\mathrm{a}}$ & $0^{\mathrm{a}}$ & $9^{a}$ & $\mathrm{p}=0.29$ \\
\hline Work in the correct seasons & $6^{a}$ & $9^{\mathrm{a}}$ & $0^{\mathrm{a}}$ & $0^{\mathrm{a}}$ & $\mathrm{p}=0.19$ \\
\hline Nothing or donnot know & $0^{\mathrm{a}}$ & $0^{\mathrm{a}}$ & $9^{a}$ & $0^{\mathrm{a}}$ & $\mathrm{P}=0.12$ \\
\hline
\end{tabular}

introduction of strategic planning and prioritisation, better stakeholder engagement and cooperation, changing the legislation relating to Prosopis, and better enforcement of legislation and contracts were also highlighted as being important among all stakeholder groups, except Workers. Improved follow-up clearing and targeting of coppicing and re-invasion were highlighted significantly more by Managers and Farmers. Farmers also mentioned that improving the quality of, and having more access to WfW area managers would help. Farmers emphasised that receiving subsidies would encourage control; this aspect is linked to the other comments regarding the provision of incentive and disincentive schemes to encourage and stimulate control. Workers mentioned that getting paid on time would help significantly to reduce apathy, unhappiness and loss of motivation. Academics specifically suggested that understanding and overcoming conflicts of interest would help to reduce certain barriers, as would an improved understanding of the taxonomy of the trees present in South Africa.

\section{Discussion}

There has been little research on barriers to effective management in the field of invasion biology and such work is needed to improve the ability of management interventions to deliver the desired outcomes. Only eight barriers relating to the management of invasive tree species have been highlighted in previous studies and these are fairly broad. They include poor data on the distribution of the invasions, a lack of coordination between stakeholders, insufficient funds and unpredictable environmental drivers (Roura-Pascual et al., 2009), as well as weak policy and institutional environments, a lack of critical information, poor implementation and a lack of capacity (UNEP, 2004), all of which were identified in this study as well. Some of the barriers identified here are also broad and have been mentioned in similar studies investigating other drivers of change such as climate change (Jantrasami et al., 2010; Lehmann et al., 2014; Spires et al., 2014). However, our study has identified important additional barriers, including corruption and indirect economic barriers, and comparisons between different stakeholder's views of barriers also yielded useful insights.

\subsection{The value of including both workshops and questionnaires in barriers research}

Using both workshops and questionnaires (each with advantages and disadvantages) enabled us to identify over a hundred barriers to management (Table 3,Fig. 2 and 3). More barriers to management were raised during workshops (100; 62 main-criteria and 38 sub-criteria) than in the questionnaires (just under 40; Table 3; Fig. 2 and 3). Workshops were relatively expensive, but helped to better understand and contextualise the barriers and provide narrative examples which do not emerge from questionnaire surveys (e.g., the experiences of farmers with corruption). The workshops clearly provided a better understanding of the dimensions and causes of barriers and how they are linked but also promoted co-learning and awareness building. The questionnaires were much cheaper, and proved useful for quantifying the frequency and the importance of different barriers, and allowed for statistical comparisons between the views of different stakeholders (Table 3 ). Case studies on barriers could be conducted using only one of the two methods used, but the two methods do complement each other and provide more depth to the research.

\subsection{Comparing barriers faced by different stakeholders}

The significant differences in the listing of barriers between different stakeholders (Figs. 2-4 and Table 3) highlight the importance of including the full range of stakeholders in such assessments. This has been lacking in past studies on barriers to management, with most studies focusing on one group. A comparison of the views between Farmers and Managers regarding the listing of three of the barriers is particularly interesting (Table 3). First, only a few Managers identified the need for strategic planning and prioritization, whereas the vast 
majority of Farmers found the lack of strategic planning and prioritization to be a significant barrier (Table 3). Secondly, poor management, supervision and efficiency were regarded as important by almost all Farmers, whereas very few Managers mentioned this. Thirdly, almost all Farmers were concerned about poor followup treatments, whereas only a quarter of Managers considered this to be important. These discrepancies point to different world views among the most important stakeholders involved in management. Clearly, Farmers are concerned about poor planning and management efficiency, and managers are not. This is probably because farmers have a genuine interest in a favourable ecological outcome, while WfW's goal of job creation is given precedence by managers. Similar views have been identified by van Wilgen and Wannenburgh (2016).

\subsection{Overcoming barriers}

Most of the barriers that we identified could be overcome relatively easily with minimal cost, whereas others would require long-term work and large scale investment. Barriers identified are fairly general and could apply to invasive species management in other parts of the world, but some are specific to a small suite of invasive species and social-economic contexts.

\subsubsection{Human and informational barriers}

Some of the human and informational barriers that we identified such as limited and inconsistent funding and capacity constraints, which are compounded by the socio-economic history of South Africa, are probably not as important in developed countries. Others, however, may be widely relevant. These include adequate funding for control projects in developing countries and building effective partnerships and ways of communicating results of research to stakeholders. As with most invasive alien species problems, a lack of knowledge constrains effective management For Prosopis in particular, research into biological control could reduce direct clearing costs and make more funding available to cover wider areas (van Klinken and Pichancourt, 2015). A sound understanding of the impacts and benefits of Prosopis is also needed to inform the development of defensible strategies for its management; this is the subject of considerable debate (Witt, 2010; Borokini and Babaloa, 2012; Shackleton et al., 2014; Walkie et al., 2016). There is also an obvious need for regular monitoring using high-level indicators, a practice that is widely recognised as essential but which is seldom implemented at an appropriately large scale (Raphael et al., 2010; Reid et al., 2009). We have also identified that, even in cases where relatively high levels of understanding exist, perceptions often prevail to the detriment of management. Examples here include the fear that biological control would become so effective that manual labour would no longer be required, and that maintaining Prosopis in the landscape would offset pressure on native trees (which it does not; Shackleton et al., 2015c,d). Awareness-raising programmes that package available information and target selected stakeholder groups should aid in reducing conflicts or misconceptions, and encourage private landowners to manage invasions. Good public awareness has been shown to be strongly correlated with implementation of climate-change adaptation responses and support for initiatives for managing invasive species across the world (Semenza et al., 2008; Garcia-Llorente et al., 2008; Verbrugge et al., 2013).

\subsubsection{Natural barriers}

Natural barriers to management include high levels of seed production, persistent seed banks, fast growth rates, the ability to coppice and biotic and abiotic vectors of spread; these are features that are shared with other invasive species such as Australian acacias (Gallagher et al., 2011; Gibson et al., 2011). These barriers are often difficult to overcome, but management interventions can be tailored to focus on such barriers. Seed production could be reduced through biological control, and spread through careful regulation of the movement of livestock-which links to managing pathways (as applicable to other invasive species as well van Wilgen et al. (2012a,b); Chuong et al. (2016). The development of more effective herbicides and ensuring their proper application could reduce the tendency for cleared sites to revert to an invaded state through coppicing. Finally, better prioritisation of interventions in space and time, such as beginning at the top of catchments and preventing spread outwards from edges of invasions could prevent re-invasions of cleared areas in lower parts of catchments and has been recommended in Australia (Grice et al., 2011).

\subsubsection{Social barriers}

The greatest number of barriers that we identified in this study were related to institutional issues. These included poor cooperation between different stakeholders, inefficient management (often linked to the absence of planning and prioritisation), corruption, and the ineffective legislation. The lack of stakeholder engagement and cooperation is a common issue in environmental management programs globally, and improved collaboration is important to overcome this (Max-Neef, 2005; Reyers et al., 2015). The employment of a coordinator to facilitate management and collaboration and co-production of research and management strategies would be highly beneficial for bridging this barrier. In addition, adherence to policy, legislation and contracts is poor for most invasive species in South Africa including Prosopis, and better enforcement would improve management.

As with several other introduced and invasive trees globally (Dickie et al., 2014; van Wilgen and Richardson, 2014), Prosopis trees cause conflict, as they can simultaneously provide benefits and generate impacts. The economic value of Prosopis for fodder and fuelwood and its intrinsic value for shade (Shackleton et al., 2015c) are leading to normative barriers and preventing management in South Africa and globally (Shackleton et al., 2014; van Wilgen and Richardson, 2014). The debate about whether or not, and to what degree, control programs should make use of utilisation schemes also present barriers to effective implementation, as it does elsewhere (e.g. in East Africa, see Witt 2010). However, we also identified conflicts that are specific to South Africa and which arise from the imperative for job creation in the WfW programme.

\subsection{Remaining research needs}

This study has identified barriers that are faced when managing a widespread invasive tree species. Most of the barriers that were identified are fairly general and would apply to other invaders and environmental conservation initiatives such as those focussing on climate change (Jones, 2010). However, some of the barriers identified in this study are specific to Prosopis or a small group of similar invasive species. In particular, those barriers related to the social-ecological context of South Africa are unique, including fraud and corruption, and the conflicts around job creation as a management approach to address the legacies of apartheid. Other invasive species groups such as mammals, fish and insects and those in early stages of invasion as opposed to being widespread are likely to face other unique barriers. Additionally, different social-ecological contexts are clearly for what barriers are faced and further research is required to explore generalities in this regard. 


\section{Conflicts of interest}

None.

\section{Acknowledgements}

We thank all the participants that were involved in the study for their time and insight. Funding was provided by the DST-NRF Centre of Excellence for Invasion Biology and the Working for Water Programme through their collaborative research project on "Integrated Management of invasive alien species in South Africa" and the National Research Foundation (grant 85417 to DMR).

\section{References}

Adger, W.N., Dessai, S., Goulden, M., Hulme, M., Nelson, D.R., Naess, L.O., Wolf, J., Wreford, A., 2009. Are there social limits to adaptation to climate change? Clim. Change 93, 335-354.

Agrawal, A., 2008. The Role of Local Institutions in Adaptation to Climate Change. World Bank, Washington, DC.

Antwi-Agyei, P., Dougill, A.J., Stringer, L.C., 2013. Barriers to climate change adaptation in sub-Saharan Africa: evidence from northeast Ghana and systematic literature review. Working Paper NO. 154. Sustainability Research Institute Paper No. 52. Centre for Climate Change Economics and Policy.

Borokini, T.I., Babaloa, F.D., 2012. Management of invasive plant species in Nigeria through economics exploitation: lessons from other countries. Manage. Biol. Invasions 3, 45-55.

Brundu, G., Richardson, D.M., 2016. Planted forests and invasive alien trees in Europe: a Code for managing existing and future plantings to mitigate the risk of negative impacts from invasions. Neobiota (in press).

Chuong, J., Huxley, J., Spotswood, E.N., Nichols, L., Mariotte, P., Suding, K.N., 2016. Cattle as dispersal vectors of invasive and introduced plants in a California annual grassland. Rangel. Ecol. Manage. 69, 52-58.

Dickie, I.A., Bennett, B.M., Burrows, L.E., Nuñez, M.A., Peltzer, D.A., Porté, A., Richardson, D.M., Rejmánek, M., Rundel, P.W., van Wilgen, B.W., 2014. Conflicting values: ecosystem services and invasive tree management. Biol. Invasions 16, 705-719.

Dzikiti, S., Schachtschneider, K., Naiken, V., Gush, M., Moses, G., Le Maitre, D.C., 2013. Water relations and the effects of clearing invasive Prosopis trees on groundwater in an arid environment in the Northern Cape, South Africa. J. Arid Environ. 90, 103-113.

Flores, G., Vega, L.R., 1998. Barriers to health care access for Latino children: a review. Fam. Med. 30, 196-205.

Gallagher, R.V., Leishman, M.R., Miller, J.T., Hui, C., Richardson, D.M., Suda, J. Trávníček, P., 2011. Invasiveness in introduced Australian acacias: the role of species traits and genome size. Divers. Distrib. 17, 844-897.

García-pérez, M.A., Núñez-antón, V., 2003. Cellwise residual analysis in two-way contingency tables. Educ. Psychol. Meas. 63, 825-839.

García-Llorente, M., Martín-López, B., González, J.A., Alcorlo, P., Montes, C., 2008. Social perceptions of the impacts and benefits of invasive alien species: implications for management. Biol. Conserv. 141, 2969-2983.

Gelland, W.F., Grenad, J.L., Marcum, Z.A., 2011. A systematic review of barriers to medication adherence in the elderly: looking beyond cost and regimen complexity. Am. J. Geriatr. Pharmacother. 9, 11-23.

Gibson, M., Richardson, D.M., Marchante, E., Marchante, H., Rodger, J.G., Stone, G.N Byrne, M., Fuentes-Ramírez, A., George, N., Harris, C., Johnson, S.D., Le Roux, J.J. Miller, J.T., Murphy, D.J., Pauw, A., Prescott, M.N., Wandrag, E.M., Wilson, J.R.U., 2011. Reproductive ecology of Australian acacias: important mediator of invasive success? Divers. Distrib. 17, 911-933.

Gifford, R., 2011. The dragons of inaction: psychological barriers that limit climate change mitigation and adaptation. Am. Psychol. 66, 290-302.

Grice, A.C., Clackson, J.R., Calver, M., 2011. Geographic differentiation of management objectives for invasive species: a case study of Hymenachne amplexicaulis in Australia. Environ. Sci. Policy 14, 986-997.

Henderson, L., 2007. Invasive, naturalized and casual alien plants in southern Africa: a summary based on the Southern African Plant Invaders Atlas (SAPIA). Bothalia 37, 215-248.

Holmes, P.M., Esler, K.J., Richardson, D.M., Witkowski, E.T.F., 2008, Guidelines for improved management of riparian zones invaded by alien plants in South Africa. S. Afr. J. Bot. 74, 538-552.

Huang, C., Veneckova, P., Wang, X., FitzGerald, G., Guo, Y., Tong, S., 2011. Constraints and barriers to public health adaption to climate change. Am. J. Preventative Med. 40, 183-190.

Jansen van Vuuren, A., Learmonth, D., 2013. Spirit(ed) away: preventing foetal alcohol syndrome with motivational interviewing and cognitive behavioural therapy. S. Afr. Fam. Pract. 55, 59-64.

Jantrasami, L.C., Lawler, J.J., Thomas, C.W., 2010. Institutional barriers to climate change adaptation in the U.S. national parks and forests. Ecol. Soc. 15 (4), 33 http://www.ecologyandsociety.org/vol15/iss4/art33/.

Jones, L., Boyd, E., 2011. Exploring social barriers to adaptation: insights from Western Nepal. Global Environ. Change 21, 1262-1274.
Jones, L., 2010. Overcoming Social Barriers to Adaptation. Overseas Development Institute, London.

Le Maitre, D.C., Versfeld, D.B., Chapman, R.A., 2000. The impact of invading alien plants on surface water resources in South Africa: a preliminary assessment. Water SA 26, 397-408.

Lehmann, P., Brenck, M., Gebhardt, O., Schaller, S., Süßbauer, E., 2014. Barriers and opportunities for urban adaptation planning: analytical framework and evidence from cities in latin america and ger. Mitig. Adaptation Strategies Glob. Change 20, 75-97. doi:http://dx.doi.org/10.1007/s11027-013-9480-0.

Lorenzoni, I., Nicholson-Cole, S., Whitmarsh, L., 2007. Barriers perceived to engaging with climate change among the UK public and their policy implications. Glob. Environ. Change 17, 445-459.

Max-Neef, M.F., 2005. Foundation of transdisciplinary. Ecol. Econ. 53, 5-16.

Moser, S.C., Ekstrom, J.A., 2010. A framework to diagnose barriers to climate change adaptation. Proc. Natl. Acad. Sci. U. S. A. 107, 22026-22031.

Ndhlovu, T., Milton-Dean, S.J., Esler, K.J., 2011. Impact of Prosopis (mesquite) invasion and clearing on the grazing capacity of semiarid Nama Karoo rangeland, South Africa. Afr. J. Range Forage Sci. 28, 129-137.

Poynton, R.J., 2009. Tree Planting in Southern Africa. Other Genera, 3. Department of Agriculture, Forestry and Fisheries, Pretoria, South Africa.

Pyšek, P., Richardson, D.M., 2010. Invasive species, environmental change and management, and ecosystem health. Annu. Rev. Environ. Resour. 35, 25-55.

Raphael, B., Baker, J., Tennant, P., Sparkes, J., McCowen, S., 2010. Stakeholder Perceptions of the Weeds of National Significance Program and Progress Against Individual Species Plans. Bureau of Rural Sciences, Canberra.

Reid, A.M., Morin, L., Downey, P.O., French, K., Virtue, J.G., 2009. Does invasive plant management aid the restoration of natural ecosystems? Biol. Conserv. 142 2342-2349.

Reyers, B., Nel, J.L., O’Farrell, P.J., Sitas, N., Nel, D.C., 2015. Navigating complexity through knowledge coproduction: mainstreaming ecosystem services into disaster risk reduction. Proc. Natl. Acad. Sci. U. S. A. 11, 7362-7368.

Richardson, D.M., Rejmánek, M., 2011. Trees and shrubs as invasive alien species-a global review. Divers. Distrib. 17, 788-809.

Richardson, D.M., Bond, W.J., Dean, W.R.J., Higgins, S.I., Midgley, G.F., Milton, S.J., Powrie, L., Rutherford, M.C., Samways, M.J., Schulze, R.E., 2000. Invasive alien organisms and global change: a south african perspective. In: Mooney, H.A. Hobbs, R.J. (Eds.), Invasive Species in a Changing World. Island Press, Washington D.C, pp. 303-349.

Richardson, D.M., 1998. Forestry trees ad invasive aliens. Conserv. Biol. 12, 18-3226.

Robinson, P.J., Gore, C.D., 2005. Barriers to Canadian municipal response to climate change. Canad. J. Urban Res. 14, 102-120.

Rouget, M., Richardson, D.M., Nel, J., Le Maitre, D.C., Egoh, B., Mgidi, T., 2004. Mapping potential ranges of major plant invaders in South Africa, Lesotho and Swaziland using climatic suitability. Divers. Distrib. 10, 475-484.

Roura-Pascual, N., Richardson, D.M., Krug, R.M., Brown, A., Chapman, R.A., Forsyth, G.G., Le Maitre, D.C., Robertson, M.P., Stafford, L., van Wilgen, B.W. Wannenburgh, A., Wessels, N., 2009. Ecology and management of alien plant invasions in South African fynbos: accommodating key complexities in objective decision making. Biol. Conserv. 142, 1595-1604.

Semenza, J.C., Hall, D.E., Wilson, D.J., Bontempo, B.D., Sailor, D.J., George, L.A., 2008 Public perception of climate change: voluntary mitigation and barriers to behaviour change. Am. J. Preventative Med. 35, 479-487.

Shackleton, S., Luckert, M., Cundill, G., Cobban, L., Clarke, C., Shackleton, R., Ndlovu, P., 2013. Transformation and barriers in the context of multiple stressors: understandings from two rural sites in the Eastern Cape, South Africa. Proceedings: Transformation in a Changing Climate: International Conference in Oslo, Norway 19-21 June 2013 136-148.

Shackleton, R.T., Le Maitre, D.C., Pasiecznik, N.M., Richardson, D.M., 2014. Prosopis: a global assessment of the biogeography, benefits, impacts and management of one of the world's worst woody invasive plant taxa. AoB Plants 6, plu027. doi: http://dx.doi.org/10.1093/aobpla/plu027.

Shackleton, R.T., Le Maitre, D.C., van Wilgen, B.W., Richardson, D.M., 2015d. Use of non-timber forest products from invasive alien Prosopis species (mesquite) and native trees in South Africa: implication for management. Forest Ecosyst. 2, 16. doi:http://dx.doi.org/10.1186/s40663-015-0040-9.

Shackleton, R.T., Le Maitre, D.C., van Wilgen, B.W., Richardson, D.M., 2015a. The impacts of invasive alien Prosopis species (mesquite) on native plants in different environments in South Africa. S. Afr. J. Bot. 97, 25-31.

Shackleton, R.T., Le Maitre, D.C., Richardson, D.M., 2015b. Prosopis invasions in South Africa. Population structures and impacts on native tree population stability. J. Arid Environ. 114, 70-78.

Shackleton, R.T., Le Maitre, D.C., Richardson, D.M., 2015c. Stakeholder perceptions and practices regarding Prosopis (mesquite) invasions and management in South Africa. Ambio 44, 529-536.

Spires, M., Shackleton, S.E., Cundill, G., 2014. Barriers to implementing planned community-based adaption in developing countries: a systematic literature review. Climate Deve. 6, 227-287.

Treiman, D.J., 2007. The legacy of apartheid: racial inequalities in the new South Africa. In: Heath, F.S., Cheung, S.Y. (Eds.), Unequal Chances: Ethnic Minorities in Western Labour Markets. Oxford University Press, Oxford.

UNEP, 2004. Removing Barriers to Invasive Plant Management in Africa. UNEP, Nairobi, Kenya.

Van den Berg, E.C., Kotze, I., Beukes, H., 2013. Detection, quantification and monitoring Prosopis in the Northern Cape province of South Africa using remote sensing and GIS. S. Afr. J. Geomatics 2, 68-81. 
Verbrugge, L.N.H., Van den Born, R.J.G., Lenders, H.J.R., 2013. Exploring public perception of non-native species from a visions of nature perspective. Environ. Manage. 52, 1562-1573.

Versfeld, D.B., Le Maitre, D.C., Chapman, R.A., 1998. Alien Invading Plants and Water Resources in South Africa. Report No. TT 99/98. Water Research Commission, Pretoria, pp. pp 276.

Vitousek, P.M., Mooney, H.A., Lubchenco, J., Melillo, J.M., 1997. Human domination of earth's ecosystems. Science 277, 494-499.

Walkie, T.T., Hoag, D., Evangelista, P.H., Luizza, M., Laituri, M., 2016. Is control through utilization a cost effective Prosopis juliflora management strategy? J. Environ. Manage. 168, 74-86.

Waller, R., Gilbody, S., 2009. Barriers to the uptake of computerized cognitive behavioural therapy: a systematic review of the quantitative and qualitative evidence. Psychol. Med. 39, 705-712.

Wilson, J.R.U., Gairifo, C., Gibson, M.R., Arianoutsou, M., Baker, B.B., Baret, S.B., Celesti-Grapow, L., DiTomaso, J.M., Dufour-Dror, J., Kueffer, C., Kull, C.A., Hoffmann, J.H., Impson, F.A.C., Loope, L.L., Marchant, E., Marchante, H., Moore, J. L., Murphy, D.J., Tassin, J., Witt, A., Zenni, R.D., Richardson, D.M., 2011. Risk assessment, eradication, and biological control: global efforts to limit Australian acacia invasions. Divers. Distrib. 17, 1030-1046.

Wise, R.M., Van Wilgen, B.W., Le Maitre, D.C., 2012. Costs, benefits and management options for an invasive alien tree species: the case of mesquite in the Northern Cape, South Africa. J. Arid Environ. 84, 80-90.
Witt, A.B.R., 2010. Biofuels and invasive species for an African perspective-a review. Bioenergy 2, 321-329.

van Klinken, R.D., Pichancourt, J.B., 2015. Population-level consequences of herbivory, climate change and source-sink dynamics of a long-lived invasive shrub. Ecol. Appl. 25, 2255-2270.

van Wilgen, B.W., Richardson, D.M., 2014. Challenges and trade-offs in the management of invasive alien trees. Biol. Invasions 16, 721-734.

van Wilgen, B.W., Wannenburgh, A., 2016. Co-facilitating invasive species control, water conservation and poverty relief: achievements and challenges in South Africa's Working for Water programme. Curr. Opin. Environ. Sustain. 19, 7-17.

van Wilgen, B.W., Forsyth, G.G., Le Maitre D.C. Wannenburgh, A., Kotze, D.F., van den Berg, E., Henderson, L., 2012a. An assessment of the effectiveness of a large, national-scale invasive alien plant control strategy in South Africa. Biol. Conserv. 148, 28-38.

van Wilgen, B.W., Cowling, R.M., Marais, C., Esler, K.J., McConnachie, M., Sharp, D. 2012b. Challenges in invasive alien plant control in South Africa. S. Afr. J. Sci. 108 1445. doi:http://dx.doi.org/10.4102/sajs.v108i11/12.1445.

Zachariades, C., Hoffmann, J.H., Roberts, A., 2011. Biological control of mesquite (Prosopis species) (Fabaceae) in South Africa. Afr. Entomol. 19, 402-415.

Zimmermann H.G., 1991. Biological control of Prosopis, Prosopis spp. (Fabaceae), in South Africa. Agriculture, Ecosystems and Environment, 37: 175-186. 